\title{
Primary Renal Care Part(I) : Possible control of proteinuria and hematuria by the method of electrical stimulations through the acupuncture needles.
}

\author{
Shima Myothant, (1) Masada Hiroyuki, (2) Takashima \\ Kenichi, (3) Nomura Hiroshi, (4) Hasegawa Masami, (5) Arao \\ Mototsugu, and (6) Shima Hisao.
}

\author{
[Director and Professor : Shima Myothant] \\ Primary Medical Care Research Institute, \\ THE OVERSEAS CULTURE AND ACEDEMIC RESEARCH SOCIETY \\ OF JAPAN, Daido Seimei Bldg., 8th Floor, Edobori, 1-Chome, Nishi-ku, \\ Osaka (P.C. 550), Tel. (06) (441)9181/2.
}

\section{Key words}

Primary renal care; higher electrical conducting points; the original Chinese acupuncture points; a pulsating current; a neurocurrent; a microampere; a grip electrode; a searching electrode a substance-like, antiproteinuria or antihematuria; deposits of neurosecretory substance ; catecholamine ; 5-hydroxytryptamine; less collagen fibers ; innervated by several nerve fibers; grouping of tiny blood vessels and lymphatic vessels ; $-41^{\circ} \mathrm{C}$ of liquid propane and lquid nitrogen; a substace-like, parotin.

Abstract

Electrical stimulations through the acupuncture needles at the higher electrical conducting points of both body and ear surface gave some good results for the control of proteinuria and hematuria. The decline of electricity corresponded to the reduction of proteinuria and hematuria after fourty time stimulations by a twelve volt electricity neurometer $(\mathrm{P}<0.001)$. Therefore, this method of stimulations through the acupuncture needles should be used for the control of proteinuria and hematuria as a primary renal care.

(1) Masada Clinic for Women's Diseases. Urology and Dermatology, Koshien nibancho 1-13, Nishinomiya City.

(2) Kyoto Mitsubishi Hospital, Katsura, Kyoto.

(3) Kyoto Mitsubishi Hospital, Katsura, Kyoto.

(4) Hasegawa Clinic, 59-1, Kanae, Nishikanki-cho, Kakogawa City. 


\section{Introduction}

The control of proteinuria and hematuria seemed to be very difficult by drug therapies only. Primary treatments of proteinuria and hematuria by drug therapies showed very effective at early four months. And then, the proteinuria and hematuria seemed to be resistant to our today therapies. However, the drug therapies used in proteinuria could give some side effects such as (1) moon-face and obesity, (2) gastric or duodenal ulcer, and (3) some damages of bone tissue. The drug therapies used in hematuria also had some side effects of (1) headache, (2) weakness, (3) neusea and vomiting, and (4) stomach troubles. There was also no good method for the control of proteinuria and hematuria as a primary renal care.

Therefore, we are interested the works of primary renal care and possible control of proteinuria and hematuria by the method of electrical stimulations through the acupuncture needles at higher electrical conduting points of both body and ear surface corresponded to the above renal disorders.

Higher electrical conducting points of body and ear surface concerned to proteinuria and hematuria could easily be detected by a tweleve volt electricity neurometer. Most of the higher electrical conducting points were located at the nearest sides of the original Chinese acupuncture point discovered in mainland China since 2000 years $(1,2)$. Nakatani and Yamashita also described the higher electrical conducting points of body surface which were detected at the nearest sides of the original Chinese acupuncture point known for several years $(3,4)$. However, their methods of detection of higher electrical conducting point were quite different from our own method $(8,9)$. There were also quite a few papers concerned on the higher electrical conducting points of ear surface $(5,6,7)$. For several years, very few workers tested the effects of electrical stimulation through the acupuncture needles on both body and ear surfaces for the treatments of neurological disorder, and they seemed to be very effective. The ear needling and electrical stimulation therapies became very popular among many patients. However, the effects of electrical stimulation at higher electrical conducting points of body and ear surface followed by the decline of electricity which corresponded to the reduction of proteinuria and hematuria did not appear in the litteratures. Our aims and objects of electrical stimulations were just to convert the body-protein in to some amino acids. Here, we speculated that the body-protein changed in to amino acids may be a substance-like, antiproteinuria or antihematuria. Therefore, the following method may be possible for the control of proteinuria and hematuria incured by drug therapies only.

\section{Materials and methods}

For body surfaces, three centimeter long steinless steel coated body needles and for ear surfaces 0.5 centimeter long stainless steel coated intradermal ear needles made tiin Japan should be used. A twelve volt electricity neurometer wasu sed for the detecons of higher electrical conducting point on both body and ear surface. This neurometer

(5) Watakushiritsu Harima Hospital, Onoe-cho, Kakogawa City.

(6) President of the Overseas Culture and Acedemic Research Society of Japan.

* The outline of this work was reported by Dr. Masada Hiroyuki at the 163th General Assembly of the Japan Urology Congress, the 24th February, 1980, Okayama University, Okayama, Japan. 
could supply two types of current such as (1) a pulsating current, and (2) a neurocurrent. A pulsating current was used for the stimulations of body surface, and a neurocurrent was used for the stimulations of ear surface. This neurometer also had a searching electrode (a negative pole) and a grip electrode (a positive pole). A grip electrode was made of stainless steel coated seven centimeter long copper cynlinder and the diameter was 2.5 centimeters. It was easy to hold up in right or left hand. The most important part for the detections of higher electrical conducting point was a searching electrode. It was made of steinless steel coated three centimeter long copper cynlinder and the diameter was one centimeter. This cynlinder had a flat tip in one end and a gold ball tip on the other end. The size of gold ball was 0.5 centimeter, and this hollow gold ball was also very useful to locate the pin-points of higher electrical conducting point within two minutes as described $(8,9)$. A pair of scissors and forceps was used for cutting out skin color surgical adhesive tapes in to small pieces. These small pieces of tape were used to cover and fix all the intradermal ear needles after implantations and stimulations so that the next stimulations could be carried out after three days. For cleaning and sterilization, $70 \%$ alcohol hibitane was used.

The procedures for electrical stimulations were divided in to two parts. The first was the insertons of body needle at higher electrical conducting points of ventral and dorsal surface (table (I)). Then the electrical stimulations were performed by a pulsating current of 50 pulses/minute for five mintes on the ventral points, and the second five minutes on the dorsal points. There were eight points on the ventral surface and the other eight points on the dorsal surface. Total times of stimulation for both ventral and dorsal points were ten minutes. The initial mean electricity of ventral points was 166. $3 \mu \mathrm{A}$ and the initial electrcity of dorsal points was $163.8 \mu \mathrm{A}$.

Table(I)

TABLE (I) HIGHER ELECTRICAL CONDUCTING POINTS OF BOTH BODY AND EAR SURFACE WHICII CORRESPONDED TO THE PROTEINURIA AND HEMATURIA WERE DETECTED BY A TWELEVE VOLT ELECTRICITY NEUROMETER AT THE NEAREST SIDES OF THE ORIGINAL CHINESE ACUPUNCTURE POINT AND THE DRUG THERAPIES USED FOR PROTEINURIA AND HEMATURIA. THIS TABLE ALSO SHOWED THE ELECTRICTTY OF EACH POINT, AND THE SPINAL AND CEREBRAL NERVE INNERVATIONS.

BODY POINTS : a) Ventral surfaces, (1) NINMYAKU ( 任 $)\left(L_{1}, s_{3}\right)=(170 \mu \mathrm{A}),(2)$ KANGEN ( Mä )

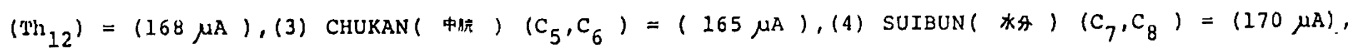

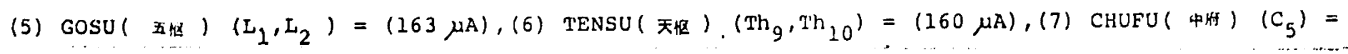
$(168 \mu \mathrm{A}),(8) \operatorname{GEKAN}(T M)($ Trig.3) $=(166 \mu \mathrm{A}),[$ Mean Electricity $=166.3 \mu \mathrm{A}]$.

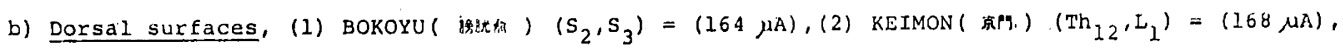

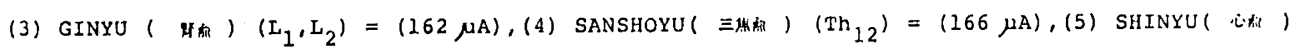
$\left(\mathrm{Th}_{6}, \mathrm{Th}_{7}\right)=(161 \mu \mathrm{A}),(6) \operatorname{KENSEI}($ 解 $)\left(\mathrm{C}_{6}, \mathrm{C}_{7}\right)=(162 \mu \mathrm{A}),(7) \operatorname{TENCHU}($ 天住 $) \cdot\left(\mathrm{C}_{4}, \mathrm{C}_{5}\right)=(163 \mu \mathrm{A})$, (9) FUCHI ( lesf,$\left(C_{2}, C_{3}\right)=(164 \mu \mathrm{A})$, [ Mean Electricity $\left.=163.8 \mu \mathrm{A}\right]$.

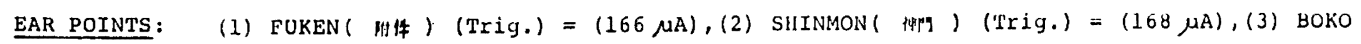
$($ Hat $)($ Faci. $)=(170 \mu A),(4) \operatorname{GIN}(\%)($ Faci. $)=(172 \mu \mathrm{A}),(5) \operatorname{sHIN}($ i $)$ (Vaga.) $=(166 \mu A)$,

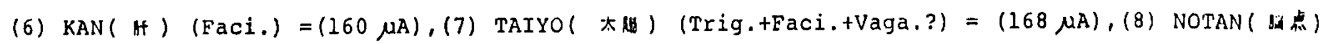

$($ Trig.+Faci.+Vaga.? $)=(170 \mu \mathrm{A}),[$ Mean Electricity $=167.5 \mu \mathrm{A}]$.

DRUG THERAPIES: a) Proteinuria, (1) Predonin, (2) Anginal, (3) Tochinamin, (4) Anturan,

b) Hematuria, (1) S-Adchnon, (2) Ophthalm K, (3) Indacin $R$, (4) Urinorm. 
The second procedure was the implantations of intradermal ear needle on both:left and right ears, and then the stimulations were performed by a neurocurrent. The time for stimulation was one minute/needle. There were eight needles on the left and the second eight needles were on the right. Total times of stimulation for both ears were sixteen minutes. After stimulations, all needles were covered with surgical tapes as above mentioned. All ear points were as shown in the table (I) and figure (I). The drug therapies used in proteinuria and hematruia were as shown in the table.

\section{Results}

Electrical stimulations through the acupuncture needles at higher electrical conducting points of body and ear surface were as shown in the table (II) and (III).

a) Proteinuria : Table (II) showed the electrical stimulations in three groups. Each group consisted of ten patients. In group (I), the electrical stimulations were performed on body surfaces only. The initial electricity was $166 \pm 5 \mu \mathrm{A}$ and the final electricity after fourty time stimulations was $142 \pm 4 \mu \mathrm{A}$. The initial protein in urine was $4+$ and the final protein in urine was $2+$. In group (II), the electrical stimulations were performed on ear surfaces only. The initial electricity was $167 \pm 3 \mu \mathrm{A}$ and the final electricity was $130 \pm 3 \mu \mathrm{A}$. The initial protein in urine was $4+$ and the final protein in urine was $2+$. Next, the electrical stimulations were performed on both body and ear surfaces. The initial electricity was $172 \pm 4 \mu \mathrm{A}$ and the final electricity was $106 \pm 6 \mu \mathrm{A}$. The initial protein in urine was $4+$ and the final protein in urine became $1+$ or \pm . Then, the drugs were treated in group (IV) for four months and in group (V) for tweleve months. The initial electricity of group (IV) was $171 \pm 7 \mu \mathrm{A}$ and the final electricity after four months became $133 \pm 5 \mu \mathrm{A}$, and the initial protein in urine was $4+$ and the final protein in urine was $2+$. In this case the initial electricty of group (V) was again considered

Table(II)

TABLE (III) ELECTRICAL STIMULATIONS THROUGH THE ACUPUNCTURE NEEDLES AT HIGHER ELECTRICAL CONDUCTING POINTS OF BODY AND EAR SURFACE BY A TWELEVE VOLT ELECTRICITY NEUROMETER INDICATED THE DECLINE OF ELECTRICITY CORRESPONDED TO THE REDUCTION OF RED BLOOD CELLS IN URINE.

\begin{tabular}{|c|c|c|c|c|c|c|c|}
\hline Patients & (No.) & $\begin{array}{l}\text { Electrical } \\
\text { stimulations for } \\
\text { (times) }\end{array}$ & $\begin{array}{l}\text { Higher electrical } \\
\text { conducting points } \\
\text { of }\end{array}$ & \multicolumn{2}{|c|}{$\begin{array}{c}\text { Electricity in } \\
(\mu \mathrm{A})\end{array}$} & \multicolumn{2}{|c|}{$\begin{array}{l}\text { Red blood cells ir. } \\
\text { urine }(- \text { to }++++)\end{array}$} \\
\hline Group I & $(10)$ & $\times 40$ & Body surfaces only & $165 \pm 2$ & $140 \pm 5^{\star \star}$ & ++++ & ++ \\
\hline Group II & $(10)$ & $\times 40$ & Ear surfaces only & $166 \pm 7$ & $120 \pm 9^{\star \star}$ & $++t+$ & ++ \\
\hline Group III & $(10)$ & $\times 40$ & Body+Ear surfaces & $170 \pm 1$ & $108 \pm 5^{\star \star}$ & +++ & $+/ \pm$ \\
\hline Group IV & $(10)^{*}$ & & Body+Ear surfaces & $168 \pm 8$ & $130 \pm 6^{\star \star}$ & ++++ & ++ \\
\hline Group V & $(10)^{\star}$ & & $"$ & $130 \pm 6$ & $134 \pm 4$ & ++ & $++/+$ \\
\hline
\end{tabular}

$M \pm S . D$. Significant differences from the initial values. ${ }^{*} \mathrm{p}<0.001$

\# Diugs treated for four months and *Drugs treated for twelve months.

No. of stimulations $=5$ minutes for ventral points and the second 5 minutes for dorsal points, and 8 minutes for right ear and the other 8 minutes for left ear. 
as $133 \pm 5 \mu \mathrm{A}$ and the drug treatments were continued for tweleve months. The final electricity in group (V) was $134 \pm 8 \mu \mathrm{A}$, and the protein in urine was remained at $2+$ or $1+$.

b) Hematuria : Table (III) showed the electrical stimulations for hematuria. In group (I), the electrical stimulations were performed on the body surfaces only. The initial electricity was $165 \pm 2 \mu \mathrm{A}$ and the final electricity after fourty time stimulations was $140 \pm 5 \mu \mathrm{A}$. The initial red blood cells in urine was $4+$ and the final red blood cells in urine was $2+$. In group (II), the electrical stimulations were performed on ear surfaces only. The initial electricity was $166 \pm 7 \mu \mathrm{A}$ and the final electricity was $120 \pm 9 \mu \mathrm{A}$. The initial red blood cells in urine was $4+$ and the final red blood cells in urine was $2+$. In group (III), the electrical stimulations were performed on body and ear surfaces. The initial electricity was $170 \pm 1 \mu \mathrm{A}$ and the final electricity was $108 \pm 5 \mu \mathrm{A}$. The initial red blood cells in urine was $4+$ and the final red blood cells in urine was $1+$ or \pm . Then, the drug treatments were performed in group (IV) for foulr months and in group (V) for tweleve months. The initial electricity was $168 \pm 8 \mu \mathrm{A}$ and the final electricity after four months became $130 \pm 6 \mu \mathrm{A}$. The initial red blood cells in urine was $4+$ and the final red blood cells in urine was $2+$. The initial electricity of group (V) was again considered as $130 \pm 6 \mu \mathrm{A}$ and the drug treatments in group (IV) were continued for tweleve months. Then, the final electricity became $134 \pm 4 \mu \mathrm{A}$ and the red blood cells in urine remained at $2+$ or $1+$.

Table(III)

TABLE (II) ELECTRICAL STIMULATIONS THROUGH THE ACUPUNCTURE NEEDLES AT HIGHER ELECTRICAL CONDUCTING POINTS OF BODY AND EAR SURFACE BY A TWELEVE VOLT ELECTRICITY NEUROME'TER INDICATED THE DECLINE OF ELECTRICITY CORRESPONDED TO THE REDUCTION OF PROTEIN IN URINE.

\begin{tabular}{|c|c|c|c|c|c|c|c|c|}
\hline \multirow{2}{*}{ Patients } & \multirow{2}{*}{ (No.) } & \multirow{2}{*}{\multicolumn{2}{|c|}{$\begin{array}{l}\text { Electrical } \\
\text { stimulations for } \\
\text { ( times ) }\end{array}$}} & \multirow{2}{*}{$\begin{array}{c}\text { Higher electrical } \\
\text { conducting points } \\
\text { of }\end{array}$} & \multicolumn{2}{|c|}{$\begin{array}{l}\text { Electricity in } \\
(\mu \mathrm{A})\end{array}$} & \multicolumn{2}{|c|}{$\begin{array}{l}\text { Protein in urine } \\
(- \text { to }+++)\end{array}$} \\
\hline & & & & & (initial) & (final) & (initial) & (final) \\
\hline Group I & (10) & $\times 40$ & & Body surfaces only & $166 \pm 5$ & $142 \pm 4^{\star \star}$ & +++ & ++ \\
\hline Group II & (10) & $\times 40$ & & Ear surfaces only & $167 \pm 3$ & $130 \pm 3^{* \star}$ & ++++ & ++ \\
\hline Group III & I (10) & $\times 40$ & & Body+Ear surfaces & $172 \pm 4$ & $106 \pm 6^{\star \star}$ & ++++ & $+/ \pm$ \\
\hline Group IV & $(10)^{\#}$ & & & Body+Ear surfaces & $171 \pm 7$ & $133 \pm 5^{\star \star}$ & t+t+ & ++ \\
\hline Group V & $(10)^{*}$ & & & $"$ & $133 \pm 5$ & $134 \pm 8$ & ++ & $++/+t$ \\
\hline
\end{tabular}

$M \pm S . D$. Significant differences from the initial values. ${ }^{\star *} \mathrm{P}<0.001$

\#Drugs treated for four months, and *Drugs treated for twelve months.

No.of stimulations $=5$ minutes for vental points and the second 5 minutes for dosal points,and 8 minutes for right ear and the other 8 minutes for left ear.

Figure (I) showed the higher electrical conducting points of both body and ear surface, the points of electrical stimulation, and the innervations of spinal and cerebral nerve. This figure also showed the decline of electricity during and after repeated stimulations. 
Figure(1)
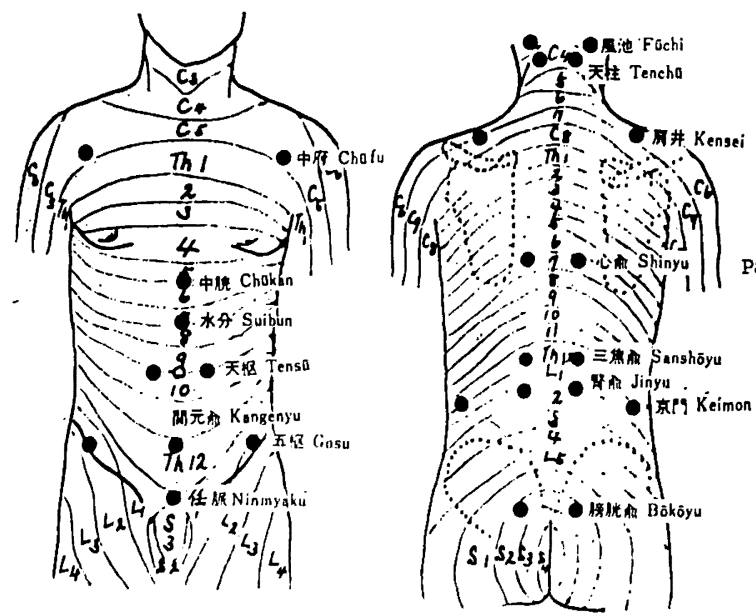

$C=$ cervial nerves; $\mathrm{Th}=$ thoracic nerves; $\mathrm{L}=$ lumbar nerves ;

$S=$ sacral nerves; Trig. = trigeminal nerves; Faci..= facial

nerves; Vaga. = vagal nerves.

FIG. (I) THIS ILLUSTRATION EXPLAINED THE POINTS OF ELECTRICAL STIMULATION AND THEIR LOCATIONS AT THE NEAREST SIDES OF THE ORIGINAL CHINESE ACUPUNCTURE POINTS, AND THE AREAS OF SPINAL AND CEREBRAL NERVE ININERVATION . THE NEUROMETER'S INDICATORS (a), (b), AND (c) INDICATED THE STEPDOWN DECLINE OF ELECTRICITY DURING AND AFTER: REPEATED STIMULATIONS.
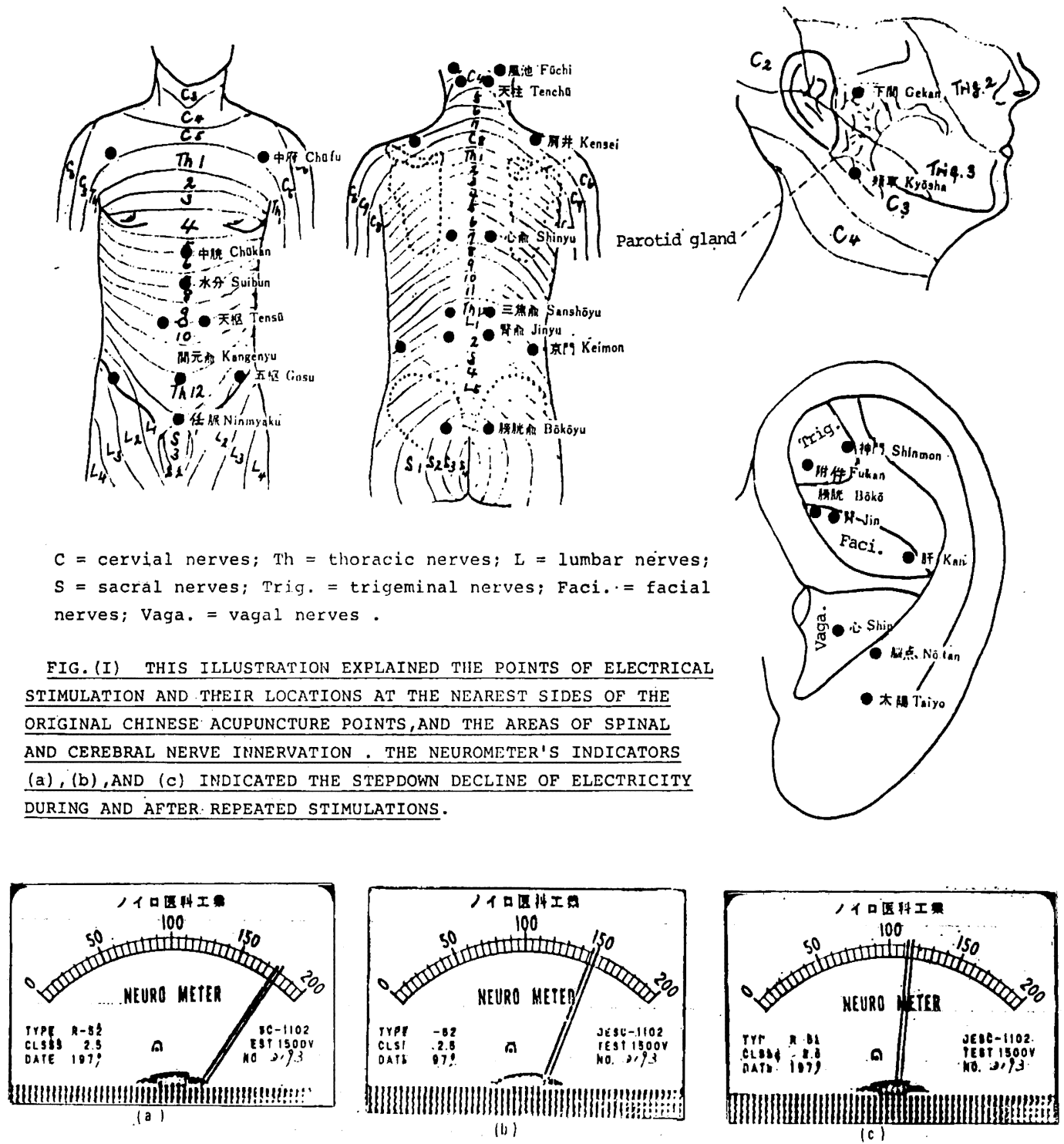

\section{Discussion}

There were several higher electrical conducting points corresponded to the proteinuria and hematuria on both body and ear surfaces. We selected the most highiest points which were present at the nearest sides of the original Chinese acupuncture point. Eight points were detected on the ventral surfaces of the body and the other eieht points were also selected on the dorsal surfaces of the body. The most interesting points were at the upper and lower borders of the parotid gland. The upper one was known as GEKEN, and the lower one was KYOSHA. Here in this case, we selected the upper points, because the electricity on the upper points were much higher than the lower ones. Eight highiest electrical conducting points were detected and selected on the left ear and the similar points were again selected on the right ear. Electrical stimulations through the highiest points seemed to be much more effective than the slightly lower 
electrical conducting points. We also found that the serum amino acids elevated in the pateints who had been taken electrical stimulations at higher electrical conducting points corresponded to various diseases such as stiff shoulder, lumbago, acute or chronic gastritis, gastric or duodenal ulcers, and many varieties of neurological disorder when compared with non-stimulated groups (9). Therefore, the electrical stimulataions through the acupuncture needles at higher electrical conducting points may change the bodyprotein in to some amino acids, because the serum amnio acids elevated since five to ten time stimulations (9). The higher electrical conducting points detected by our own method also showed less collagen fibers, innervated by several nerve fibers, and grouping of tiny blood vessels and lymphatic vessels (8), the same as described by Lusiani (10). We also tested about five cases of punch biopsy of higher electrical conducting point for the observations of sympathetic, and parasympathetic nerve cell product such as catecholamine and 5 -hydroxyptamine by freezing and drying method $\left(-41^{\circ} \mathrm{C}\right.$ of liquid propane and liquid nitrogen). The sections observed by flourescence microscope showed green to yellow color (9). Therefore, there may be some deposits of neuro-secretory substance produced by sympathetic and parasympathetic nervous system such as catecholamine and 5-hydroxytryptamine when there were some neurological involvements secondary to the other diseases.

We also found many cases of proteinuria and hematuria which had the neurogenic control. There were many kinds of renal disease which showed proteinuria and hematuria. The renal disorders due to IgA nephropathy did not response to our today drug therapies. Therefore we sometime confirmed the types of renal disorder by renal biopsies. All cases in this report were some common cases of purely proteinuria and purely hematuria due to acute or chronic glomerulonephritis. Sometimes, some cases showed the hematuria, but there were no evidences of nephritis confirmed by renal biopsies.

The proteinuria and hematuria could control by the method of electrical stimulations as above mentioned. As shown in the table (II) and (III), the electrical stimulations on body together with ear could give much response than the stimulations of the body and ear separately.

Drug treatments for both proteinuria and hematuria showed rather effective at early four months, and then they seemed to be resistant in later periods of tweleve months. We also found that the combined therapies of electrical stimulations and drugs gave much more response to proteinuria and hematuria than the separated therapies.

We considered that the decline of electricity corresponded to the reduction of proteinuria and hematuria may be due to some electrical blocking effects of spinal level and medullopontine level. The higher electrical points on both ventral and dorsal surfaces of the body were also located at the nearest sides of spinal nerve innervation, and the cerebral nerve innervations in ear points were, (1) trigeminal nerves, (2) facial nerves, and (3) vagal nerves (table (I) and figure (I)). Body stimulations may give the blocking effects on spinal level and ear stimulations may block on the medullopontine level.

The second reason was that the electrical stimulations of body surface may convert the body-protein in to some amino acids. The elevation of serum amino acids such as (1) tyrosine, (2) alanine, (3) lysine, (4) ornithine, (5) proline, (6) serine, (7) 
histidine, (8) valine, (9) glutamic acid, and (10) $\mathrm{NH}_{3}$ could be observed in 60 patients with neurological disorders comparing to the non-stimulated control groups (10). Therefore, these amino acids may become a substance-like, antiproteinuria or antihematuria.

The third reason was that the selected points on upper borders of parotid gland (GE-KEN) and their electrical stimulations may liberate a substance-like, parotin for the control of proteinuria and hematuria.

\section{Summary}

1) (a) The higher electrical conducting points corresponded to the proteinuria and hematuria could be detected by a twelve volt electricity neurometer (DC type) on both body and ear surfaces.

(b) There were several higher electrical conducting points correponded to the proteinuria and hematuria. We only selected the most highiest points because the most highest points seemed to be much effective than the slightly lower ones.

(c) The higher electrical conducting points on both upper borders of parotid gland (GEKEN) should be used for the control of proteinuria and hematuria.

(d) Most of the higher electrical conducting points were at the nearest sides of the original Chinese acupuncture points known for several years.

2) Electrical stimulations through the acupuncture needles at higher electrical conducting points of both body and ear surface could contrul the proteinuria and hematuria. The decline of electricity $(\mathrm{P}<0.001)$ corresponded to the reduction of protein and red blood cells in urine (from $4+$ to $1+$ or \pm ). The renal function tests also showed very much improved (unpublished data).

3) We speculated that there were two possible pathways of electrical blocking effect on, (1) spinal levels and (2) medullopontine levels for the control of proteinuria and hematuria.

4) We also considered that the body-protein may change in to some amino acids after repeated electrical stmulations. These amino acids may be a substance-like, antiproteinuria or antihematuria.

5) A possible method for the control of proteinuria and hematuria was described.

\section{Summary translations}

\section{要約 :}

1）（a）蛋白尿之血尿に関連のある良導点は、人体及び耳の表面に12ボルトのノイロメーター （NAーDCタイプ）によって探知するととが可能である。

(b) 蛋白尿と血尿に関連のある良導点は数力所存在した。その中で最も電流量の多い良導 点のみを選出した。その理由は、電流量の少い良導点より効果があるように思われたか らである。

(c) 耳下腺（下関）の両端部での良導点は、蛋白尿之血尿を制御するのに効果がある。

(d) ほとんどの良導点が、数千年前より知られた中国古来の針治療点に近隣していた。

2) 人体及び耳の表面の良導点に針を刺入し、電流刺激を与えるととによって、蛋白尿と血尿 をコントロールするととが可能である。電流の低下（ $\mathrm{P}<0.001 ）$ は、尿中の蛋白質並びに 赤血球の低減 $(4+$ から1+或いは士）と関係がある。腎蔵の働き（腎機能）も改善を示して いる (末発表)。

3 ）(1)脊䯣と(2)蛋白尿と血尿を制御する延䯣橋に効果のある電気ブロックの伝導路が $2 つ$ つ 
と考えられる。

4) 電流刺激を反復すると、体内の蛋白質がアミノ酸に変化すると考えられる。これらのアミ ノ酸は物質のようなもの、反蛋白永か反血尿と考えられる。

5 ）蛋白尿と血尿をコントロールする方法を記述した。

\section{References}

1) Lee, J. F. and Cheung, C.S. : Current acupuncture therapies, Medical Interflow Publishing House, Hong Kong, 1978.

2) An outline of Chinese acupuncture, the acedemy traditional Chinese medicine, Paramon press, Oxford, New York, Toronto, Sydney, Paris, Frankfurt, 1975.

3) Nagatani,Y. and Yamashita, K. : Ryodoraku acupuncture, Published by Ryodoraku Research Institute, Tokyo, Osaka, 1977.

4) Nagatani, Y. : Rinsho no tabiki Ryodoraku, Published by Ryodoraku Kenchusho, 1962.

5) Practical ear needling therapy, medicine and health publishing Co., Hong Kong, 1977.

6) Kobayashi, Y. : Chukoku no atarashi mimishin ryoho, Osaka Kobayashi Ryodoraku Kenchusho, 1973.

7) Ming Hang Cho. : The method of ear needling and clinical applications, 1978.

8) Shima Myothant et al. : Morphological, histological and histochemical observations of the higher electrical conducting points of human skin (in preparation).

9) Shima Myothant et al. : Elevations of serum amino acids after repeated electrical stimulations at the higher electrical conducting points of both ventral and dorsal surface of the body (in preparation).

10) Lusiani, R. L. : Direct observation and photography of electroconductive points on human skin, Amer.J. of Acupuncture, 4. 311. 1978.

\section{Ackn،wlegements}

This work was supported by the Scientific foundations of the Overseas Culture and Acedemic Research Society of Japan for human welfare. The author extended his thanks to the director of Watakushiritsu Harima Hospital, Dr. Arao Mototsugu for his cooperations in serum amino acid measurements of the patients who were treated with the electrical stimulations through the acupuncture needles, and Takashima Yasuko for her help in the computed neuro-electricity of higher electrical conducting points. 